\title{
Terapi Non Farmakologi dalam Penanganan Diagnosis Nyeri Akut pada Fraktur : Systematic Review
}

\author{
Risnah $^{1)}$, Risnawati HR ${ }^{2)}$, Maria Ulfah Azhar ${ }^{3)}$, Muhammad Irwan ${ }^{4)}$ \\ ${ }_{1,2,3}$ Prodi Keperawatan FKIK UIN Alauddin Makassar \\ ${ }^{4}$ Prodi Keperawatan Fakultas Ilmu Kesehatan \\ Universitas Sulawesi Barat \\ Email : Risnah@uin-alauddin.ac.id
}

\begin{abstract}
Penelitian ini merupakan penerapan terapi non farmakologik penanganan nyeri dari berbagai perbandingan. Desain Systematic review. Populasi berasal dari Artikel terkait dengan Fraktur. Pengumpulan data sumber literature pada penelitian ini adalah Google Schoolar, Pubmed dan Portal Garuda dengan menggunakan kata kunci "Nyeri", 'Pain", "Fracture"”'Non Farmakologik Fraktur" dan "Fraktur" dengan kriteria Artikel tahun 2015-2018 Fulltext Artikel yang sesuai dengan topic, Terdapat ISSN, Jurnal yang terbit di Asia Tenggara, Merupakan jurnal intervensi untuk mengatasi nyeri pada pasien fraktur, Merupakan intervensi non farmakologi, Intervensi yang efisien berdasarkan hasil penelitian, dan Intervensi yang mudah dilakukan. Hasil Penelitian ini adalah Setelah menggumpulkan data dan informasi, semua data tersebut diseleksi sesuai dengan kriteria inklusi dan ekslusi kemudian di diseleksi kerelevanan menggunakan Duffy's Research Appraisal Checklist Approach, dilanjutkan dengan analisis komparatif untuk melihat perbandingan antara pikiran utama karya tulis ini dengan beberapa teori yang relevan, dan untuk selanjutnya memberikan rekomendasi teknik non farmakologi yang dapat digunakan untuk mengurangi nyeri pada pasien fraktur. Berdasarkan sembilan artikel yang terpilih tentang terapi non farmakologik dalam penanganan diagnosis nyeri membuktikan bahwa $100 \%$ terapi non farmakologik efektif dalam menurunkan nyeri pada pasien fraktur. Teknik non farmakologik yang digunakan dalam jurnal yang terpilih yaitu, teknik distraksi, relaksasi nafas dalam, Kompres dingin (Cold Pack) dan Range of Motion (ROM). Kesimpulan : Berdasarkan 9 jurnal yang terpilih sesuai dengan kriteria inklusi, terapi non farmakologik yang efektif dalam penanganan diagnosis nyeri pada fraktur adalah distraksi pendengaran, relaksasi nafas dalam, kompres dingin (cold pack), Range of Motion (ROM)
\end{abstract}

Kata Kunci:, Fraktur, Nyeri, Pain, Fracture, Non Farmakologi Fraktur

\section{PENDAHULUAN}

Kehidupan sehari-hari dengan aktivitas manusia masing-masing yang semakin padat untuk mengejar perkembangan zaman. Manusia tidak luput dari fungsi normal musculoskeletal utamanya tulang yang menjadi alat gerak utama bagi manusia.Tulang membentuk rangka penunjang dan pelindung bagi manusia tulang dan tempat melekatnya otot yang menggerakan kerangka tubuh, namun, fungsi tulang dapat terganggu karena mengalami fraktur (Mansjoer, 2008). Fraktur biasanya disebabkan oleh trauma yang substansial seperti fraktur pelpis akibat kecelakaan, atau minor dan berulang seperti patah tulang metatarsal balerina atau atlet jarak jauh. Patah tulang patologis terjadi akibat penyakit yang mendasarinya seperti Penyakit Paget, osteoporosis, osteomilitis atau tumor yang mengakibatkan kelemahan tulang (Whiteing, 2008)

Fraktur merupakan terputusnya kontinuitas tulang. Patah tulang dapat terjadi karena jatuh, trauma, sebagai akibat pukulan langsung atau karena kelemahan pada tulang itu sendiri. Beberapa fraktur juga disebabkan karena proses penyakit seperti osteoporosis yang dapat menyebabkan fraktur-fraktur patologis (Reeves, 2001).

Departemen Kesehatan Republik Indonesia (Depkes RI, 2013) menyebutkan bahwa dari jumlah kecelakaan yang terjadi dengan presentasi $5,8 \%$ korban cedera atau sekitar 8 juta orang menderita fraktur dengan jenis fraktur yang paling banyak terjadi yaitu fraktur pada bagian ekstremitas atas sebesar 36,9\% dan ekstremitas bawah sebesar 65,2\%. Badan Kesehatan Dunia 
(WHO) mencatat pada tahun 2011-2012 terdapat 5,6 juta orang meninggal dunia dan 1,3 juta orang menderita fraktur akibat kecelakaan lalu lintas. Menurut Depkes RI 2011, dari sekian banyak kasus fraktur di Indonesia, fraktur pada ekstremitas 2 bawah akibat kecelakaan memiliki prevalensi yang paling tinggi diantara fraktur lainnya yaitu sekitar 46,2\%. Dari 45.987 orang dengan kasus fraktur ekstremitas bawah akibat kecelakaan, 19.629 orang mengalami fraktur pada tulang femur, 14.027 orang mengalami fraktur cruris, 3.775 orang mengalami fraktur tibia, 970 orang mengalami fraktur pada tulang-tulang kecil di kaki dan 336 orang mengalami fraktur fibula.

- Berdasarkan Data dan Informasi Profil Kesehatan Indonesiatahun 2016 kejadian bencana menurut jenis bencana kecelakaan transportasi tahun 2014 angka presentasi sebesar 47,7\%, tahun 2015 sebesar 84\% dan tahun 2016 sebesar 74\% (Kemenkes RI, 2017). Berdasarkan data dari Departemen Kesehatan RI tahun 2013 didapatkan sekitar 8 juta orang mengalami fraktur dengan jenis fraktur yang berbeda dan penyebab yang berbeda. Dari hasil survey tim Depkes RI didapatkan $25 \%$ penderita fraktur yang mengalami kematian, $45 \%$ mengalami catat fisik, $15 \%$ mengalami stress psikologis seperti cemas atau bahkan depresi, dan 10\% mengalami kesembuhan dengan baik (Depkes RI 2013). Sedangkan menurut World Hearth Oraganization (WHO) tahun 2013 menyebutkan bahwa kecelakaan lalu lintas mencapai $120.222 \mathrm{kali}$ atau $72 \%$ dalam setahun.

Insiden fraktur femur di Indonesia merupakan yang paling sering yaitu sebesar 39\% diikuti fraktur humerus (15\%), fraktur tibia dan fibula $(11 \%)$, dimana penyebab terbesar fraktur femur adalah kecelakaan lalu lintas yang biasanya disebabkan oleh kecelakaan mobil, motor, atau kendaraan rekreasi $(62,6 \%)$ dan jatuh $(37,3 \%)$ dan mayoritas adalah pria (63,8\%).4,5\% Puncak distribusi usia pada fraktur femur adalah pada usia dewasa (15 - 34 tahun) dan orang tua (diatas 70 tahun).

Hasil studi yang dilakukan oleh (Rahma,2018) menyatakan bahwa sebagian besar kualitas hidup pasien fraktur terganggu pada domain fungsi fisik dan keterbatasan fisik, sedangkan kualitas hidup ditinjau dari mental secara keseluruhan baik. Diperlukan edukasi untuk meningkatkan kualitas hidup pasien pasca operasi.

Salah satu tanda dan gejala dari fraktur adalah nyeri. Nyeri merupakan gejala yang paling sering ditemukan pada gangguan muskoskeletal. Nyeri merupakan pengalaman sensorik atau emosional yang berkaitan dengan kerusakan jaringan aktual atau fungsional, dengan onset mendadak atau lambat (SDKI, 2016). Nyeri yang dirasakan pada pasien fraktur adalah nyeri tajam dan tertusuk-tusuk (Helmi, 2012).

Nyeri dapat diatasi dengan terapi farmakologi dan terapi non farmakologi yaitu teknik relaksasi, massage, kompres, terapi musik, murottal, distraksi, dan guided imaginary. (Smeltzer et al., 2008). Teknik non farmakologi merupakan salah satu intervensi keperawatan secara mandiri untuk mengurangi nyeri yang dirasakan oleh pasien. Teknik relaksasi memberikan individu kontrol diri ketika nyeri muncul dan dapat digunakan pada seseorang sehat ataupun sakit (Perry \& Potter, 2005).

Teknik non farmakologi banyak digunakan untuk mengatasi nyeri pada pasien fraktur, selain itu terapi non farmakologi tidak memiliki efek samping. Dalam studi ini, penulis ingin membahas tentang teknik non farmakologi untuk mengatasi nyeri pada pasien fraktur.

\section{METODE}

Sumber artikel pada penelitian ini adalah database google schoolar, pubmed, portal garuda dengan kriteria inklusi, artikel tahun 2015-2018, jurnal yang terbit di Asia Tenggara, merupakan jurnal intervensi untuk mengatasi nyeri pada pasien fraktur, merupakan intervensi non farmakologi, intervensi yang efisien berdasarkan hasil penelitian dan intervensi yang mudah dilakukan.

\section{STUDI SELEKSI}

Setelah menggumpulkan data dan informasi, semua data diseleksi sesuai dengan kriteria inklusi yaitu Artikel tahun 2015-2018 Fulltext Artikel yang 
sesuai dengan topic, Terdapat ISSN, Jurnal yang terbit di Asia Tenggara, Merupakan jurnal intervensi untuk mengatasi nyeri pada pasien fraktur, Merupakan intervensi non farmakologi, Intervensi yang efisien berdasarkan hasil penelitian, dan Intervensi yang mudah dilakukan. Kemudian diseleksi kerelevanannya menggunakan Duffy's Research Appraisal Checklist Approach, dilanjutkan dengan analisis kompratif untuk melihat perbandingan antara pikiran utama karya tulis ini dengan beberapa teori yang relevan, dan untuk selanjutnya memberikan rekomendasi teknik non farmakologi yang dapat digunakan untuk menurunkan nyeri yang dirasakan pada pasien fraktur.

\section{HASIL}

Berdasarkan hasil pencarian artikel penelitian, didapatkan 363 jurnal yang membahas tentang fraktur, namun terdapat 34 jurnal yang membahas tentang terapi non farmakologi untuk menangani nyeri pada pasien fraktur berdasarkan kriteria inklusi dan lembar penilaian Duffy's Research Appraisal Checklist Approach. Penulis mengambil artikel dilihat dari segi aplikabilitas intervensi dan sesuai dengan kriterian inklusi yang telah ditetapkan yaitu artikel tahun 2015-2018 fulltext artikel yang sesuai dengan topic, terdapat ISSN, jurnal yang terbit di Asia Tenggara, merupakan jurnal intervensi untuk mengatasi nyeri pada pasien fraktur, merupakan intervensi non farmakologi, intervensi yang efisien berdasarkan hasil penelitian serta intervensi yang mudah dilakukan. Terapi non farmakologis tersebut di antaranya terapi musik, meditasi dzikir, kompres dingin, terapi Asmaul Husna, cold pack, relaksasi nafas dalam dan ROM.

Terdapat 9 Jurnal yang terpilih berdasarkan kriteria inklusi dan lembar penilaian Duffy's Research Appraisal Checklist Approach,dari 9 jurnal yang terpilih terdapat 4 terapi non farmakologi yang efektif dalam menurunkan skala nyeri pada pasien fraktur yaitu, teknik distraksi, relaksasi nafas dalam, kompres dingin (Cold Pack) dan Range of Motion (ROM)

Distraksi Pendengaran
Hasil yang didapatkan terdapat 5 jurnal yang menggunakan distraksi pendengarn dalam menangani nyeri pada pasien fraktur. Distraksi pendengaran dari 5 jurnal tersebut adalah terapi musik instrumental dan terapi mendengarkan Asmaul Husna. Berdasarkan hasil penelitian terapi tersebut efekti dalam menurunkan skala nyeri pada pasien fraktur. Hal tersebut sejalan dengan penelitian (Rostini, 2017) membuktikan bahwa terdapat pengaruh pemberian terapi musik terhadap tingkat nyeri pada pasien fraktur di rumah sakit umum nene malomo kabupaten sidrap, dari hasil penelitian tersebut terjadi penurunan tingkat nyeri dengan mean 8,33 menjadi mean 7,36.

Distraksi pendengaran merupakan salah satu tindakan untuk mengatasi nyeri pada fraktur, individu yang mengalami kesakitan akan merasa rileks saat mendengarkan musik atau sejenisnya. pelepasan opioid endogen, atau disasosiasi. Musik atau sejenisnya memberikan efek distraksi dan sisasosiasi opiat endogen di beberapa fosi didalam otak, termasuk hipotalamus dan sistem limbik (Joyce \& Jane, 2014). Musik merupakan sebuah rangsangan pendengaran

yang terorganisir yang terdiri atas melodi, ritme, harmoni, timbre, bentuk dan gaya. Jenis musik yang efektif dalam mengatasi nyeri adalah musik klasik karena musik klasik memiliki tempo yang berkisar antara $60-80$ beats per menit setara dengan detak jantung manusia. Musik klasik bermanfaat untuk membuat seseorang menjadi rileks, menimbulkan rasa aman dan sejahtera, melepaskan rasa gembira dan sedih (Ani \& Diah, 2016).

\section{Relaksasi Nafas Dalam}

Hasil yang didapatkan terdapat 2 jurnal yang menggunakan relaksasi nafas dalam untuk mengatasi nyeri yang dirasakan oleh pasien fraktur. Hasil penelitian yang didapatkan menurut dengan hasil relaksasi nafas dalam efektif digunakan untuk menurunkan skala nyeri yang dirasakan oleh pasien pre maupun post operasi fraktur. Hal tersebut sesuai dengan penelitian yang dilakukan oleh (Leila \& Reza, 2018) membuktikan bahwa hasil uji statistik dengan menggunakan uji wilcoxon didapatkan nilai 
p-value : 0,001 dapat disimpulkan bahwa terdapat pengaruh teknik relaksasi nafas dalam terhadap nyeri pada pasien fraktur,

Relaksasi nafas dalam dapat memberikan perubahaan yang dirasakan pada oleh tubuh secara fisiologis yang bersifat emosional serta sensorik. Relaksasi nafas dalam merupakan salah satu terapi non farmakologi yang mmberikan efek relaksasi yang dapt menurunkan skala nyeri dengan merangsang susunan saraf pusat yaitu otak dan sumsum tulang belakang guna untuk memproduksi pengeluaran hormone edorphine yang membantu untuk menurunkan skala nyeri yang dirasakan oleh individu. (S.B. AJI, 2015)

Selain menurunkan nyeri pada pasien fraktur relaksasi nafas dalam juga dapat menurunkan berbagai macam nyeri yang dirasakan oleh pasien misalnya nyeri yang dirasakan oleh pasien post section Caesar, hal tersebut sejalan dengan penelitian yang dilakukan oleh (Kristiarini, 2013) dengan hasil penelitian yang didapatkan terdapat pengaruh relaksasi autogenic terhadap penurunan nyeri pada ibu post section Caesar dengan hasil uji statistik yang didapatkan yaitu p-value: 0,000.

\section{Kompres Dingin (Cold Pack)}

Hasil yang didapatkan terdapat 2 jurnal yang menggunakan teknik non farmakologi yaitu kompres dingin (Cold Pack) hasil penelitian dari kedua jurnal tersebut adalah terdapat pengaruh kompres dingin terhadap penurunan skala nyeri yang dirasakan oleh pasien fraktur. Kompres dingin (Cold Pack) eektif digunakan untuk menurunkan nyeri yang dirasakan oleh pasien. Hal tersebut juga sesuai dengan penelitian yang dilakukan oleh (E.Purnamasari. 2014) dengan hasil penelitian sebelum diberikan kompres dingin didapatkan 21 responden dengan nyeri sedang setelah diberikan kompres dingin terdapat 2 responden yang tidak nyeri dan 19 responden yang nyeri ringan. Hasil uji statistik didapatkan nilai p-value :0,000 dapat disimpulkan bahwa kompres dingin efekti digunakan untuk menurunkan nyeri yang dirasakan oleh pasien fraktur.

Kompres dingin merupakan salah satu tindakan keperawatan dan banyak digunakan untuk menurunkan nyeri. Sensasi dingin yang dirasakan memberikan efek fisiologis yang dapat menurunkan respon inflamasi, menurunkan alirah darah, mampu menurunkan edema serta mengurangi rasa nyeri local. Secara fisiologis, 10-15 menit setelah diberikan kompres dingin terjadi proses vasokonstriksi dari efek releks otot polos yang dapat timbul akibat stimulasi system saraf otonom serta mampu menstimulasi pengeluaran hormone endorphine. (Novita, 2010)

Bleakley et al (2007), me;lakukan penelitian terkait penangan cedera dengan menggunakan es, hasil yang didapatkan yaitu jaringan lunak yang cedera dapat menurunkan nyeri serta menghilangkan pembengkakan. Terapi es ini dianjurkan 1-3 hari setelah cedera atau pada saat fase cedera akut. Selama itu, pembuluh darah disekitar jaringan yang terluka membuka nutrisi dan cairan masuk ke dalam darah untuk membantu penyembuhan jaringan.

\section{Range of Motion (ROM)}

Hasil yang didapatkan terdapat 1 jurnal yang menggunakan Range of motion (ROM) sebagai terapi non farmakologi untuk menurunkan skalai nyeri. Hasil penelitian yang didapatkan ROM efektif digunakan untuk menurunkan skala nyeri pada pasien post operasi fraktur. Hal tersebut sejalan dengan penelitian yang dilakukan oleh (Yuanik, 2014) didapatkan nilai $p$-value: 0,000 yang dapat disimpulkan bahwa ROM Exercise dini pada pasien post operasi fraktur ekstremitas bawah (fraktur femur dan fraktur cruris) terhadap lama hari rawat.

ROM merupakan upaya pengobatan yang penatalaksanaannya menggunakan latihan gerak baik secara aktif maupun secara pasif. ROM diberikan untuk mengatasi gangguan ungsi gerak, mecegah komplikasi, mengurangi nyeri dan edema dan melatih aktivitas akibat operasi. Rom diberikan pada bagian yang mudah kontraski dan relaksasi sehingga pasien yang telah menjalani operasi fraktur tidak mengalami kekakuan otot. (Hendrik, 2012)

Penelitian yang dilakukan oleh Tati (2015) dengan judul pengaruh latihan ROM aktif terhadap kekuatan otot pada pasien post operasi fraktur tibia, hasil uji statistik dengan menggunakan Paired 


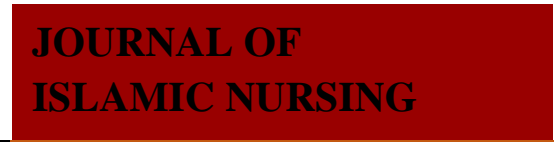

sample t-test didapatkan nilai p-value: 0,000 yang dapat disimpulkan bahwa terdapat pengaruh latihan ROM aktif terhadap kekuatan otot pada pasien post operasi fraktur tibia. 
Table 1. Artikel Terapi Non Farmakologik pada Fraktur

\begin{tabular}{|c|c|c|c|c|c|c|c|}
\hline $\mathrm{NO}$ & Peneliti & Desain Penelitian & Tujuan & Ukuran Sampel & Intervensi & Instrument & Hasil \\
\hline 1 & $\begin{array}{l}\text { Leila Aini, Reza } \\
\text { Reskita. } \\
\text { Program Studi } \\
\text { Ners, STIK Siti } \\
\text { Khadijah } \\
\text { Palembang, } \\
\text { Indonesia }\end{array}$ & $\begin{array}{l}\text { Pra- } \\
\text { Eksperimental } \\
\text { dengan } \\
\text { rancangan One } \\
\text { Group pretest- } \\
\text { posttest }\end{array}$ & $\begin{array}{l}\text { Untuk mengetahui } \\
\text { pengaruh teknik } \\
\text { relaksasi nafas dalam } \\
\text { terhadap penurunan } \\
\text { nyeri pad pasien fraktur }\end{array}$ & $\begin{array}{l}30 \text { responden , usia 16- } \\
25 \text { tahun, grade fraktur } \\
1-3 \text {, diberikan } \\
\text { analgetik yang sama. }\end{array}$ & $\begin{array}{l}\text { Pemberian } \\
\text { relaksasi nafas } \\
\text { dalam }\end{array}$ & $\begin{array}{l}\text { Menggunakan } \\
\text { lembar pengukuran } \\
\text { skala nyeri } \\
\text { Numeric Rating } \\
\text { Scale (NRS) }\end{array}$ & $\begin{array}{l}\text { Setelah diberikan teknik relaksasi nafas dalam } \\
\text { didapatkan skala nyeri } 2-6 \text { sedangkan setelah di } \\
\text { berikan relaksasi nafas dalam didapatkan skala nyeri } \\
\text { 1-5. Hasil uji statistic didpatkan } p \text {-value: } 0,001 \text { maka } \\
\text { disimpulkan ada pengaruh teknik relaksasi nafas } \\
\text { dalam terhadapt penurunan nyeri pada pasien fraktur }\end{array}$ \\
\hline 2 & $\begin{array}{l}\text { Fadli. } \\
\text { STIKES } \\
\text { Muhammadiyah } \\
\text { Sidrap }\end{array}$ & $\begin{array}{l}\text { Quasi } \\
\text { Eksperiment } \\
\text { dengan Pre test } \\
\text { and Posttest } \\
\text { design without } \\
\text { control }\end{array}$ & $\begin{array}{l}\text { Untuk mengetahui } \\
\text { pengaruh distraksi } \\
\text { pendengaran terhadap } \\
\text { intensitas nyeri pada } \\
\text { pasien fraktur }\end{array}$ & $\begin{array}{l}18 \text { responden, klien } \\
\text { yang mengalami } \\
\text { fraktur pada } \\
\text { ekstremitas bawah }\end{array}$ & $\begin{array}{l}\text { Pemberian } \\
\text { distrasi } \\
\text { pendengaran }\end{array}$ & $\begin{array}{l}\text { Menggunakan } \\
\text { lembar pengukuran } \\
\text { skala nyeri } \\
\text { Numeric Rating } \\
\text { Scale (NRS) }\end{array}$ & $\begin{array}{l}\text { Nilai rata-rata sebelum intervensi didapatkan mean } \\
6,55 \text { sedangkan nilai minimunnya yaitu } 5 \text { dan } \\
\text { maximum } 8 \text { namun setelah diberikan intervensi } \\
\text { didapatkan mean } 5,08 \text { dan nilai minimunnya yaitu } 3 \\
\text { dan maximum } 7 \text {. Hasil uji wilcoxon didapatkan nilai } \\
\text { p-value: } 0,001 \text { sehingga dapat disimpulkan bahwa } \\
\text { terdapat pengaruh distraksi pendengaran terhadap } \\
\text { intenitas nyeri pasien fraktur }\end{array}$ \\
\hline 3 & $\begin{array}{l}\text { Putri Wulandini, } \\
\text { Andalia Roza, } \\
\text { Santi Riska Safitri. } \\
\text { Keperawatan } \\
\text { Universitas } \\
\text { Abdurrab }\end{array}$ & $\begin{array}{l}\text { Quasy } \\
\text { Eksperiment } \\
\text { dengan } \\
\text { rancangan Pre } \\
\text { test and post test } \\
\text { design with } \\
\text { control }\end{array}$ & $\begin{array}{l}\text { Untuk mengetahui } \\
\text { efektifitas terapi Asmaul } \\
\text { Husna terhadap } \\
\text { penuruna skala nyeri } \\
\text { pada pasien fraktur }\end{array}$ & $\begin{array}{l}30 \text { responden. } 15 \\
\text { kelompok intervensi } \\
\text { dan } 15 \text { kelompok } \\
\text { control. }\end{array}$ & \begin{tabular}{|l|} 
Pada kelompok \\
Intervensi \\
diberikan \\
terapi \\
mendengarkan \\
Asmaul Husna \\
sedangkan \\
pada kelompok \\
Kontrol tidak \\
diberikan \\
perlakun \\
\end{tabular} & $\begin{array}{l}\text { Lembar } \\
\text { pengukuran } \\
\text { menggunakan } \\
\text { Numeric rating } \\
\text { Scale (NRS) }\end{array}$ & $\begin{array}{l}\text { Hasil yang didapatkan sebelum diberikan terapi } \\
\text { mendengarkan Asmaul Husnah didapatkan mean } \\
\text { skala nyeri 5,2667 sedangkan pada kelompok } \\
\text { Kontrol didapatkan mean skala nyeri 4,6667. } \\
\text { Setelah diberikan terapi mendenggarkan Asmaul } \\
\text { Husna ddapatkan mean skala nyeri 4,0000 dan pada } \\
\text { kelompok Kontrol didapatkan 4,6667. Hasil uji } \\
\text { statistic didapatkan } p \text {-value }: 0,000 \text { dapat } \\
\text { disimpulkan bahwa ada pengaruh pemberian terapi } \\
\text { Asmaul Husna terhadap penurunan skala nyeri pada } \\
\text { pasien fraktur }\end{array}$ \\
\hline 4 & $\begin{array}{l}\text { Machebya Novita, } \\
\text { Mario E.Katuuk, } \\
\text { Vandri D.Kallo. } \\
\text { Program Studi } \\
\text { Ilmu Keperawatan } \\
\text { Fakultas } \\
\text { Kedokteran } \\
\text { Universitas Sam } \\
\text { Ratulangi }\end{array}$ & $\begin{array}{l}\text { Pre } \\
\text { Eksperimental } \\
\text { dengan } \\
\text { rancangan One } \\
\text { Group Pretest } \\
\text { and posttes } \\
\text { design }\end{array}$ & $\begin{array}{l}\text { Untuk mengetahui } \\
\text { pengaruh terapi musik } \\
\text { instrumental terhadap } \\
\text { perubahan skala nyeri } \\
\text { pada pasien pre operasi } \\
\text { fraktur }\end{array}$ & $\begin{array}{l}16 \text { responden dengan } \\
\text { menggunakan Non } \\
\text { Random (non } \\
\text { Probability) sampling } \\
\text { dengan metode } \\
\text { Purposive Sampling }\end{array}$ & $\begin{array}{l}\text { Pemberian } \\
\text { terapi musik } \\
\text { instrumental }\end{array}$ & $\begin{array}{l}\text { Lembar } \\
\text { pengukuran nyeri }\end{array}$ & $\begin{array}{l}\text { Hasil yang didapatkan sebelum diberikan terapi } \\
\text { musik instrumental didapatkan } 17 \text { orang dengan } \\
\text { skala nyeri sedang (4-6) } 1 \text { orang dengan skala nyeri } \\
\text { ringan (1-3) setelah diberikan intervensi terapi } \\
\text { musik instrumental didapatkan } 3 \text { orang dengan skala } \\
\text { nyeri sedang (4-6) } 15 \text { orang dengan skala nyeri } \\
\text { ringan (1-3). Hasil uji Wilcoxon didapatkan nilai } p \text { - } \\
\text { Value: } 0,0001 \text { dapat disimpulkan bahwa ada } \\
\text { pengaruh terapi musik instrumental terhadap } \\
\text { perubahan skala nyeri pada pasien pre operasi } \\
\text { fraktur. }\end{array}$ \\
\hline 5 & $\begin{array}{l}\text { Rivaldy Djamal, } \\
\text { Sefty Rompas, }\end{array}$ & $\begin{array}{l}\text { Quasy } \\
\text { Eksperimen }\end{array}$ & $\begin{array}{l}\text { Untuk mengetahui } \\
\text { pengaruh terapi musik }\end{array}$ & $\begin{array}{l}32 \text { responden. } 16 \\
\text { kelompok intervensi }\end{array}$ & $\begin{array}{l}\text { Pemberian } \\
\text { terapi musik }\end{array}$ & $m b$ & $\begin{array}{l}\text { Sebelum diberikan intervensi didapatkan pada } \\
\text { kelompok intervensi dan Kontrol yaitu skala nyeri }\end{array}$ \\
\hline
\end{tabular}




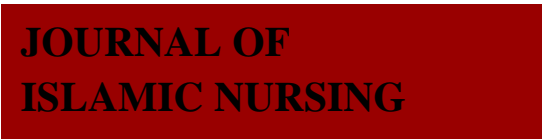

\begin{tabular}{|c|c|c|c|c|c|c|c|}
\hline & $\begin{array}{l}\text { Jeavery Bawotong. } \\
\text { Program Studi } \\
\text { Ilmu Keperawatan } \\
\text { Program Studi } \\
\text { Ilmu Keperawatan } \\
\text { Fakultas } \\
\text { Kedokteran, } \\
\text { Universitas Sam } \\
\text { Ratulangi Manado } \\
\end{array}$ & $\begin{array}{l}\text { dengan } \\
\text { rancangan } \\
\text { Pretest and } \\
\text { postets with } \\
\text { Kontrol group }\end{array}$ & $\begin{array}{l}\text { terhadap penurunan } \\
\text { skala nyeri pada pasien } \\
\text { fraktur }\end{array}$ & $\begin{array}{l}\text { dan } 16 \text { kelompok } \\
\text { kontrol }\end{array}$ & & & $\begin{array}{l}\text { sedang } 13 \text { orang dan nyeri ringan } 3 \text { orang. Setelah } \\
\text { diberikan intervensi terapi musik didapatkan } 1 \text { orang } \\
\text { dengan nyeri ringan dan } 5 \text { orang dengan nyeri } \\
\text { sedang. Hasil uji statistic didapatkan nilai } p \text {-value: } \\
\text { 0,000 dapat disimpulkan bahwa terdapat pengaruh } \\
\text { yang signifikan terapi musik terhadap penurunan } \\
\text { skal nyeri pada pasien fraktur }\end{array}$ \\
\hline \multicolumn{8}{|c|}{ le 1 (Contd.) } \\
\hline 6 & $\begin{array}{l}\text { Devi Mediarti, } \\
\text { Rosnani, Sosya } \\
\text { Mona Seprianti. } \\
\text { Poltekes } \\
\text { Kemenkes } \\
\text { Palembang Jurusan } \\
\text { Keperawatan, } \\
\text { Palembang }\end{array}$ & $\begin{array}{l}\text { Eksperimental } \\
\text { dengan } \\
\text { rancangan One } \\
\text { group pre test- } \\
\text { post test }\end{array}$ & $\begin{array}{l}\text { Untuk mengetahui } \\
\text { pengaruh pemberian } \\
\text { kompres dingin terhadap } \\
\text { nyeri pada pasien fraktur } \\
\text { ekstremitas tertutup }\end{array}$ & $\begin{array}{l}15 \text { orang responden } \\
\text { dengan kriteria inklusi } \\
\text { semua pasien fraktur } \\
\text { ekstremitas yang } \\
\text { mengalami nyeri, } \\
\text { pasien yang dirawat } \\
12-24 \text { jam, pasien tidak } \\
\text { dalam pengruh obat } \\
\text { analgetik(kompres } \\
\text { diberikan } 4 \text { jam setelah } \\
\text { pemberian analgetik) }\end{array}$ & $\begin{array}{l}\text { Pemberian } \\
\text { kompres } \\
\text { dingin }\end{array}$ & $\begin{array}{l}\text { Lembar } \\
\text { pengukuran Nyeri }\end{array}$ & $\begin{array}{l}\text { Hasil penelitian yang didapatkan sebelum diberikan } \\
\text { kompres dingin didapatkan rata-rata skala nyeri } \\
\text { yaitu 6,40 dengan nilai minimum yaitu } 5 \text { sedangkan } \\
\text { nilai maksimum yaitu 8, setelah diberikan kompres } \\
\text { dingin didapatkan rata-rata sakala nyeri yaitu 3,53 } \\
\text { dengan nilai minimum } 2 \text { dan nilai maksimum } 6 . \\
\text { Hasil uji statistic didapatkan nilai } p \text {-value: } 0,000 \\
\text { yang artinya terdapat pengaruh pemberian kompres } \\
\text { dingin terhadap nyeri pada pasien fraktur } \\
\text { ekstremitas tertutup }\end{array}$ \\
\hline 7 & $\begin{array}{l}\text { Made Martini, Ari } \\
\text { Pertama } \\
\text { Watiningsih, } \\
\text { Kadek Lisnayani. } \\
\text { Prodi S1 Stikes } \\
\text { Buleleng }\end{array}$ & \begin{tabular}{|l|} 
Pra- \\
Eksperimental \\
dengan \\
rancangan One \\
group pre-test \\
design
\end{tabular} & $\begin{array}{l}\text { Untuk menganalisis } \\
\text { pengaruh distraksi } \\
\text { (Musik klasik ) terhadap } \\
\text { penurunan nyeri pada } \\
\text { pasien post operasi } \\
\text { fraktur }\end{array}$ & $\begin{array}{l}22 \text { responden yang } \\
\text { dipilih menggunakan } \\
\text { teknik Non Probality } \\
\text { sampling yaitu } \\
\text { purposive sampling } \\
\text { dengan kriteria inklusi } \\
\text { dan ekslusi }\end{array}$ & $\begin{array}{l}\text { Pemberian } \\
\text { terapi distraksi } \\
\text { (musik klasik) }\end{array}$ & $\begin{array}{l}\text { Lembar pengukura } \\
\text { nyeri Numeric } \\
\text { Rating Scale (NRS) }\end{array}$ & $\begin{array}{l}\text { Hasil penelitian yang didapatkan sebelum diberikan } \\
\text { terapi distraksi (musik klasik) rata-rata intensitas } \\
\text { nyeri responden berada dinilai minimum } 2 \text { dan } \\
\text { maksimum 6. Setelah diberikan terapi distraksi } \\
\text { (musik klasik) didapatkan rata-rata nyeri responden } \\
\text { berada pada nilai minimum } 1 \text { dan maximum 5. Hasil } \\
\text { uji statistik dengan menggunakan Paired dependen } \\
\text { T-test didapatkan nilai p-value: } 0,000 \text { dapat } \\
\text { disimpulkan bahwa ada pengaruh terapi distraksi } \\
\text { (musik klasik) terhadap penurunan skala nyeri pada } \\
\text { pasien post operasi fraktur }\end{array}$ \\
\hline 8 & $\begin{array}{l}\text { Orien Permana, } \\
\text { Sofiana } \\
\text { Nurchayati, } \\
\text { Herlina. } \\
\text { Program Studi } \\
\text { Ilmu Keperawatan } \\
\text { Universitas Riau }\end{array}$ & $\begin{array}{l}\text { Quasy } \\
\text { Eksperimen } \\
\text { dengan } \\
\text { rancangan Non- } \\
\text { Equivalent } \\
\text { Control group }\end{array}$ & $\begin{array}{l}\text { Untuk mengetahui } \\
\text { pengaruh ROM terhadap } \\
\text { intensitas nyeri pada } \\
\text { pasen Post operas fraktur } \\
\text { ekstremitas bawah }\end{array}$ & $\begin{array}{l}30 \text { responden dibagi } \\
\text { menjadi } 2 \text { kelompok } \\
\text { yaitu } 15 \text { responden } \\
\text { pada kelompok } \\
\text { intervensi dan } 15 \\
\text { responden pada } \\
\text { kelompok kontrol }\end{array}$ & $\begin{array}{l}\text { Pemberian } \\
\text { tindakan ROM } \\
\text { selama } 20 \\
\text { menit }\end{array}$ & $\begin{array}{l}\text { Lembar observasi } \\
\text { dengan } \\
\text { menggunakan } \\
\text { Numeric Rating } \\
\text { Scale }(\mathrm{NRS})\end{array}$ & $\begin{array}{l}\text { Hasil yang didapatkan intensitas nyeri sebelum } \\
\text { diberikan tindakan ROM pada kelompok intervensi } \\
\text { yaitu dengan mean 4,71 dan kelompok kontrol } \\
\text { dengan mean 4,91. Setelah diberikan tindakan ROM } \\
\text { intensitas nyeri pada kelompok intervensi yaitu } \\
\text { dengan mean 3,27 sedangkan pada kelompok } \\
\text { kontrol dengan mean 4,71 }\end{array}$ \\
\hline 9 & $\begin{array}{l}\text { Agung Kristanto, } \\
\text { Fitri Arofiati. }\end{array}$ & $\begin{array}{l}\text { Quasy } \\
\text { eksperimen } \\
\text { dengan } \\
\text { rancangan Pre }\end{array}$ & $\begin{array}{l}\text { Untuk mengetahui } \\
\text { efektifitas kompres } \\
\text { dingin cold pack dengan } \\
\text { relaksasi nafas dalam }\end{array}$ & $\begin{array}{l}30 \text { responden dibagi } \\
\text { menjadi } 2 \text { kelompok } \\
\text { yaitu } 15 \text { responden } \\
\text { pada kelompok }\end{array}$ & \begin{tabular}{|l|} 
Pada kelompok \\
intervensi \\
diberikan \\
kompres
\end{tabular} & $\begin{array}{l}\text { Lembar } \\
\text { pengukuran } \\
\text { menggunakan } \\
\text { lembar pengukuran }\end{array}$ & $\begin{array}{l}\text { Hasil yang didapatkan tidak ada perbedaan skla } \\
\text { nyeri pada kedua kelompok, sebelum diberikan } \\
\text { intervensi didapatkan skala nyeri berada pada skala } \\
4-5 \text { setelah diberikan intervensi pemberian kompres }\end{array}$ \\
\hline
\end{tabular}




\begin{tabular}{|c|c|c|c|c|c|c|c|}
\hline & & $\begin{array}{l}\text { test }- \text { post test } \\
\text { with control } \\
\text { group }\end{array}$ & $\begin{array}{l}\text { untuk menurunkan nyeri } \\
\text { pada pasien post ORIF }\end{array}$ & $\begin{array}{l}\text { eksperimen dan } 15 \\
\text { responden pada } \\
\text { kelompok kontrol }\end{array}$ & $\begin{array}{l}\text { dengan Cold } \\
\text { Pack } \\
\text { sedangkan } \\
\text { pada kelompok } \\
\text { kontrol } \\
\text { diberikan } \\
\text { teknik } \\
\text { relaksasi nafas } \\
\text { dalam }\end{array}$ & $\begin{array}{l}\text { nyeri Visual } \\
\text { Analogi Scale } \\
\text { (VAS) }\end{array}$ & $\begin{array}{l}\text { dengan Cold Pack memberikan efek penurunan } \\
\text { nyeri lebih banyak yaitu 2-3 poin sedangkan teknik } \\
\text { relaksasi nafas dalam effek penuruna nyeri sebesar } \\
1 \text { poin. }\end{array}$ \\
\hline
\end{tabular}




\section{KESIMPULAN}

Berdasarkan hasil penelitian dari sembilan artikel tersebut menyatakan bahwa terapi non farmaologi yang efekti dalam menurunkan skala nyeri pada pasien fraktur adalah Distraksi pendengaran, Relaksasi nafas dalam, kompres dingin (Cold Pack) dan Range of Motion (ROM). Kelima terapi tersebut direkomendasikan untuk digunakan karena tekniknya sederhana, tidak membutuhkan alat dan bahan yang banyak, tidak memerlukan kemampuan khusus untuk menerapkannya dan dapat dilakukan oleh semua pasien fraktur yang mengeluh nyeri.

\section{REFERENSI}

Ani Astuti, Diah Merdekawati.2016. Pengaruh Terapi Musik Klasik TerhadapPenurunan Tingkat Skala Nyeri Pasien Post Operasi.Vol.10.No.3.http://dx.doi.org/xxxxx/JIT.200 8.350-526

Andarmoyo, S. 2013. Konsep Dan Proses Keperawatan Nyeri. Yogyakarta: Ar-Ruzz Aroyah \&Novita. 2012. Terapi dingin (cold therapy) dalam penanganan cedera olahraga . Jurusan Pendidikan dan Rekreasi FIK UNY

Arief Mansjoer (2010), Kapita Selekta Kedokteran, edisi 4, Jakarta : Media Aesculapius

Black,M.J. \& Hawks,H J, (2009). Medical surgical nursing : clinical management for continuity of care, 8th ed. Philadephia: W.B. Saunders Company

Bleakley, Sean o'connor, Mark A Tully, Laurence G Rocke, Domnhall C MacAuley and Suzanne M McDonough. (2007). Study protocol: The PRICE study (Protection Rest Ice Compression Elevation): design of a randomised controlled trial comparing standard versus cryokinetic ice applications in the management of acute ankle sprain. BMC Musculoskeletal Disorders 2007, 8:125 doi:10.1186/1471-2474-8-125
Carolyn \& Louise. 2001. Measurement of Nursing Outcomes Second Edition, Volume 1 : Measuring Nursing Performance in Practice, Education and Research. Springer Publishing Company

Davies, T.H., \& Crombie, K. (2009). What is a systematic review. Hayward GroupLtd, Hayward

Dimascio L. 2010. Classification and management of acute wounds and open fractures. Surgery (Oxford)

Gde Rastu Adi Mahartha, dkk. (2010). Manajemen Fraktur Pada Trauma Muskuloskeletal. Bagian/SMF Ilmu Bedah Fakultas Kedokteran Universitas Udayana/Rumah Sakit Umum Pusat Sanglah

Gillian, M. (2008). Pain Management Guidelines. Journal of Practical Nursing 28. (2)

Hendrik. H. Damping, 2012. Pengaruh penatalaksanaan terapi latihan terhadap kepuasan pasien fraktur di Irna A.RSUP. Prof. Dr. R.D. Kandou Manado. JUIPERDO

Helmi, Zairin N. (2012). Buku Ajar Gangguan Muskuloskeletal. Jakarta: Salemba medika.

Ignatavicius, D. D., \& Workman, m. L. (2010). Medical - Surgical Nursing: Clients - Centered Collaborative Care. Sixth Edition, $1 \& 2$. Missouri: Saunders Elsevier

Jazuli, Ahzami Samiun. 2006. Al Hayatu fil-Qur'an Al-karim terjemahan oleh Sari Nurlita, Miftahul Jannah dkk. Jakarta:Gema Insani

Joyce M. Black \& Jane Hokanson Hawks. (2014). Keperawatan Medikal Bedah : Manajemen Klinis Untuk Hasil Yang Diharapkan Edisi 8 Buku 1. Terjemah. Songapore: Salemba Medika.

Kalfas, I. (2001). Principles of bone healing. Neurosurgical Focus, 10(4), 1-4. Normal Process of Bone Healing. Poster from EBI Medical Systems.

Kementrian Agama, RI, Al-Qur'an dan Terjemahnya. 2015.

Kolcaba, K \& DiMarco, M. A. (2005). Comfort theory and its application to pediatric nursing. Pediatric Nursing, 31 (3), 187-194 
Kolcaba, K, Tilton, C, \& Drouin C (2006). Comfort theory a unifying framework to enhance the practice environment. The Journal of Nursing administration, 36 (11), 538-544

Kozier, et al. (2010). Foundamentals of nursing consepts process, and practice, New Jersey: Pearson Prentise Hall.

Lenni \& Lola. (2018). Pengaruh Terapi Dingin Cryotherapy terhadap Penurunan Nyeri pada Fraktur Ekstremitas Tertutup. Jurnal Kesehatan Hesti Wira Sakti. No.6 Vol 2 Tahun 2018

Lewis, et al. (2011). Medical Surgical Nursing Assesment and Management of Clinical Problems Volume 2. Mosby: ELSEVIER

Novita Intan. 2010. Dasar-Dasar Fisioterapi pada Cedera Olahraga. Yogyakarta

Whiteing NL (2008) Fractures: pathophysiology, treatment and nursing care. Nursing Standard. 23, 2, 49-57. Date of acceptance: August 52008

Reeves CJ, Potter, P.A, Perry, A.G. (2005) Buku Ajar Fundamental Keperawatan : Konsep, Proses, dan Praktik.Edisi 4.Volume 2.Alih Bahasa : Renata Komalasari,dkk.Jakarta:EGC.

Rostini, dkk. 2017. Pengaruh Pemberian Terapi Musik terhadap Penurunan Tingkat Nyeri pada PAsien Fraktur. Volume 6 Nomor 2 Bulan Desember Tahun 2017. Jikp Jurnal Ilmiah Kesehatan Pencerah Roux G and Lockhart R, (2001), Keperawatan Medikal Bedah, Buku I, (Penerjemah Joko Setyono), Jakarta : Salemba Medika
Pinzon Rizaldiy (2014) Esesmen Nyeri. Yogyakarta Betha Grafika

Prasetyo, S. N. (2010). Konsep dan Proses Keperawatan Nyeri. Yogyakarta : Graha Ilmu.

Setyo Bayu Aji, dkk. 2015. Efektifitas Antara Relaksasi Autogenik Dan Slow Deep Breathing Relaxation Terhadap Penurunan Nyeri Pada Pasien Post Orif Di Rsud Ambarawa

Siefert, M.L (2002). Concept analysis of comfort. Nursing Forum, 37 (4), 16-23

Solomon, Apley. (2010). Buku Ajar Orthopedi dan Fraktur Sistem Apley ; Alih Bahasa Edi Nugraha, Edisi Tujuh, Jakarta, Widya Medika, , halaman 364373

Sherwood, Lauralee. 2012. Fisiologi Manusia:Dari Sel ke Sistem, Ed, 6. Jakarta:EGC

Sjamsuhidajat \& de jong. (2010). Buku Ajar Ilmu Bedah.Jakarta: EGC

Smeltzer, Suzanne C \& Bare, Brenda G. (2002). Keperawatan Medikal Bedah. Jakarta: EGC

Tati Murti, (2015). Pengaruh Latihan ROM Aktif terhadap Kekuatan Otot pada Pasien post operasi Fraktur Tibia. NESTRA Vol.3 No. 4

Tamsuri, A. (2007). Konsep dan penatalaksanaan nyeri, Jakarta: EGC.

Yani Trihandayani, S.Kep,Ners.1 Ita Karnita. 2013. Pengaruh Terapi Musik Terhadap Penurunan Intensitas Nyeri Akibat Perawatan Luka Post Operasi Diruang Vii Rsud Gunung Djati Cirebon. Dosen Akper Muhammadiyah Cirebon 


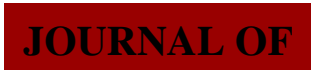

ISLAMIC NURSING 